\title{
Tingkat Kepatuhan Penggunaan Ramuan Jamu Saintifik Hiperglikemia pada Pasien Diabetes Melitus di Rumah Riset Jamu Hortus Medicus B2P2TOOT Tawangmangu
}

\section{The Level of Adherence to The Use of Scientific Hyperglycemia Herbal Remedies in Patients With Diabetes Mellitus at The Research Center for Herbal Medicine Hortus Medicus B2P2TOOT Tawangmangu}

\author{
Hartono $^{1}$, Livia Ary Kusumastuti ${ }^{2}$ \\ tono_navsol@yahoo.co.id \\ ${ }^{1}$ Program Studi DIII Farmasi, Sekolah Tinggi Ilmu Kesehatan Nasional, Surakarta
}

\begin{abstract}
Abstrak
Diabetes mellitus adalah penyakit degeneratif yang disebabkan oleh gangguan metabolisme kronis yang ditandai dengan gula darah tinggi. Tingkat kepatuhan dengan terapi pengobatan dapat meningkatkan keberhasilan terapi. Penelitian ini bertujuan untuk mengetahui tingkat kepatuhan pasien terhadap penggunaan obat herbal ilmiah hiperglikemia pada penderita diabetes mellitus di Rumah Penelitian Obat Herbal Hortus B2P2TOOT Tawangmangu. Penelitian ini adalah penelitian deskriptif, menggunakan pengumpulan data yaitu purposive sampling. Instrumen yang digunakan untuk pengujian kepatuhan menggunakan kuesioner MMAS-8. Data yang dipelajari meliputi usia, jenis kelamin, jenis obat, pendidikan, pekerjaan, durasi penderitaan, dan tingkat kepatuhan pasien serta faktor-faktor yang terkait dengan kepatuhan. Hasil penelitian terhadap 96 responden menunjukkan bahwa termasuk kategori tingkat kepatuhan pasien terhadap penggunaan obat herbal ilmiah hiperglikemia adalah tinggi $48 \%$, tingkat kepatuhan sedang $43 \%$ dan tingkat kepatuhan rendah $9 \%$. Berdasarkan hasil penelitian dapat disimpulkan bahwa tingkat kepatuhan penggunaan obat herbal ilmiah hiperglikemia pada penderita diabetes mellitus di Rumah Penelitian Obat Herbal Hortus B2P2TOOT Tawangmangu tergolong kategori tinggi yaitu $48 \%$.
\end{abstract}

Kata kunci: Diabetes mellitus, jamu ilmiah, kepatuhan, B2P2TOOT Tawangmangu

\begin{abstract}
Diabetes mellitus is a degenerative disease caused by chronic metabolic disorders characterized by high blood sugar. The levels compliance with treatment therapy can improve the success of therapy. This research purpose to determine the level of patient compliance level of use of scientific herbal medicine hyperglycemia in diabetes mellitus in Hortus Medicus Herbal Medicine Research House B2P2TOOT Tawangmangu. This research is a descriptive research, using data collection namely purposive sampling. The instruments used for compliance testing using MMAS-8 questionnaire. Data studied inclued age, gender, type of medicine, education, occupation, duration of suffering, and level of patient compliance as well as factors related to compliance. Results research on 96 respondents showed that including the category levels of patient
\end{abstract}


adherence to the use of scientific herbal medicine hyperglycemia was high $48 \%$, moderate adherence rate of $43 \%$ and low adherence level of $9 \%$. Based on the results of the study it can be concluded that compliance level of use of scientific herbal medicine hyperglycemia in diabetes mellitus in Hortus Medicus Herbal Medicine Research House B2P2TOOT Tawangmangu classified as high category $48 \%$.

Keywords : Diabetes mellitus, scientific herbal medicine, compliance, B2P2TOOT Tawangmangu

\section{Pendahuluan}

Diabetes melitus adalah penyakit kronis yang terjadi ketika tubuh tidak dapat memproduksi insulin yang cukup atau tidak bisa menggunakan insulin dengan efektif. Seseorang dengan penyakit diabetes tidak dapat menyerap glukosa dengan benar sehingga glukosa tersebut tetap berada dalam sirkulasi darah atau disebut hiperglikemia yang dapat merusak jaringan tubuh setiap waktu. Kerusakan ini dapat menyebabkan kelumpuhan dan komplikasi kesehatan (International Diabetes Federation, 2013).

Pada tahun 2015, Indonesia menempati peringkat ke-7 di dunia dengan prevalensi penderita diabetes tertinggi bersama dengan China, India, Amerika Serikat, Brazil, Rusia, dan Meksiko yaitu sebesar 10 juta. Diabetes dengan komplikasi merupakan penyebab kematian tertinggi ketiga di Indonesia. Persentase kematian akibat diabetes di Indonesia merupakan yang tertinggi kedua setelah Srilanka. Prevalensi diabetes di Indonesia menunjukkan kecenderungan meningkat yaitu dari 5,7\% (2007) menjadi 6,9\% (2013). 2/3 orang dengan diabetes di Indonesia tidak mengetahui dirinya memiliki diabetes dan berpotensi untuk mengakses layanan kesehatan dalam kondisi terlambat (sudah dengan komplikasi) (World Health Organization, 2016).

Data studi global, pada tahun 2013 melaporkan lebih dari 21 juta kelahiran dipengaruhi oleh diabetes selama hamil. Diabetes juga telah menyebabkan 5,1 juta kematian. Pada tahun 2013 sebanyak 382 juta orang telah terkena penyakit diabetes, dan diperkirakan akan meningkat menjadi 592 juta pada tahun 2035 dengan peningkatan paling tinggi adalah diabetes tipe II (International Diabetes Federation, 2013).
Mengingat akan peningkatan prevalensi penyakit diabetes melitus yang tinggi memberikan dampak terjadinya pola pengobatan pada pasien diabetes melitus. Tujuan pengobatan pada pasien diabetes melitus untuk mencegah komplikasi dan meningkatkan keberhasilan terapi. Keberhasilan terapi tidak hanya meliputi tentang ketepatan dosis, ketepatan pemilihan obat, tetapi juga kepatuhan dalam pengobatan. Mengingat akan terapi yang digunakan pada pasien diabetes melitus dilakukan jangka panjang, maka kepatuhan juga berkontribusi dalam terapi yang dilakukan (Ainni, 2017). Program yang dikenal dengan "saintifikasi jamu" yang merupakan terobosan untuk mengangkat jamu menjadi produk berbukti ilmiah dan diharapkan dapat digunakan dalam fasilitas pelayanan kesehatan, sedangkan produk dari kumpulan ramuan jamu yang diperoleh dari studi klinik yang telah dilakukan oleh rumah riset jamu dinamakan jamu saintifik, artinya jamu empirik yang telah tersaintifikasi, setelah menjadi jamu saintifik maka dapat dimanfaatkan oleh dokter atau tenaga kesehatan di fasilitas pelayanan kesehatan primer (Kemenkes, 2017). Program saintifikasi jamu hanya dapat dilakukan di fasilitas pelayanan kesehatan yang telah mendapatkan izin atau memenuhi persyaratan yang telah ditetapkan. Salah satunya dilakukan di Klinik Saintifikasi Jamu Hortus Medicus di Balai Besar Penelitian Pengembangan Tanaman Obat dan Obat Tradisional (B2P2TOOT) Tawangmangu. Badan Litbang Kesehatan yang merupakan klinik jamu yang telah terakreditasi kedalam tipe A yang dapat menyelenggarakan program saintifikasi jamu (Ahmad, 2012). 
Perilaku tidak patuh pada umumnya akan meningkatkan risiko yang terkait dengan masalah kesehatan dan semakin memperburuk penyakit yang sedang diderita. Dalam suatu penelitian didapatkan bahwa 30\% penderita diabetes melitus yang rutin melakukan pengobatan merupakan jumlah dari $50 \%$ penderita yang sadar bahwa dirinya mengidap diabetes. Kesulitan-kesulitan dalam mengelola pengobatan berkala tersebut menyebabkan penderita diabetes melitus dapat menjadi tidak patuh dalam mengontrol kadar gula darahnya (Oktadiansyah, 2014).

Penelitian serupa dilakukan oleh Ainni (2017) mengenai gambaran tingkat kepatuhan pada pasien diabetes melitus tipe-2 di RSUD dr. Tjitrowardojo Purworejo masih tergolong dalam tingkat kepatuhan rendah $(39,6 \%)$. Faktor penentu kepatuhan penggunaan obat yaitu faktor pendidikan dan faktor pekerjaan, keduanya memiliki hubungan yang bermakna dengan kepatuhan minum obat dengan arah korelasi yang berlawanan. Terdapat pengaruh yang signifikan antara jumlah item obat yang diberikan selama 1 bulan terhadap skor kepatuhan Morisky Medication Adherence Scale (MMAS-8) pada pasien diabetes melitus tipe-2 dengan nilai $p 0,012(p<0,05)$, dengan pengaruh yang rendah dengan nilai sebesar $11,6 \%$.

Penggunaan obat tradisional secara umum dinilai relatif lebih aman daripada penggunaan obat modern. Hal ini disebabkan karena obat tradisional memiliki efek samping yang relatif lebih sedikit dari pada obat modern. Berdasarkan hal di atas peneliti ingin mengetahui tingkat kepatuhan penggunaan ramuan jamu saintifik hiperglikemia pada pasien diabetes melitus di Rumah Riset Jamu Hortus Medicus (B2P2TOOT) Tawangmangu.

\section{Metode Penelitian}

Penelitian ini dilakukan untuk mengetahui gambaran tingkat kepatuhan penggunaan ramuan jamu saintifik hiperglikemia pada pasien diabetes melitus di Rumah Riset Jamu Hortus Medicus Tawangmangu pada bulan Desember tahun 2018. Teknik yang digunakan dalam pengambilan sampel adalah teknik purposive sampling. Sampel yang digunakan sebagai responden yaitu sebanyak 102 orang, tetapi terdapat 6 responden yang tidak memenuhi kriteria inklusi karena tidak bersedia menjadi responden. Melalui teknik purposive sampling hanya didapatkan 96 responden sebagai sampel yang kemudian diperoleh persebaran karakteristik subjek penelitian berdasarkan umur, jenis kelamin, jenis item obat, pendidikan, pekerjaan, dan lama menderita penyakit diabetes melitus.

\section{Analisis Data}

Pada analisis data dengan menggunakan Kuesioner kepatuhan adalah nilai kepatuhan mengkonsumsi obat 8 skala baru untuk mengukur kepatuhan penggunaan obat dengan rentang nilai 0 sampai 8 . Kategori respon terdiri dari ya dan tidak. Tingkat kepatuhan didapatkan dari total skor yang dimasukkan ke dalam Kategori tinggi (total skor 8), Kategori sedang (total skor 6-7), Kategori rendah (total skor 1-5).

\section{Hasil Dan Pembahasan}

\section{Karakteristik Responden}

Distribusi pasien diabetes melitus di

Rumah Riset Jamu Hortus Medicus B2P2TOOT Tawangmangu berdasarkan jenis kelamin, umur, jenis obat, pendidikan, pekerjaan, lama menderita dapat dilihat pada Tabel 1.

\section{Karakteristik pasien diabetes melitus berdasarkan usia}

Pada penelitian ini pengambilan data usia pasien digunakan untuk mengetahui populasi pasien DM di Rumah Riset Jamu Hortus Medicus B2P2TOOT Tawangmangu. Distribusi frekuensi pasien DM berdasarkan usia dapat dilihat pada (tabel 1).

Berdasarkan (tabel 1) menunjukkan hasil distribusi frekuensi pasien diabetes melitus berdasarkan usia di Rumah Riset Jamu Hortus Medicus B2P2TOOT Tawangmangu dapat diketahui bahwa kategori usia terbanyak yaitu pada usia di atas 50 tahun sebanyak 73 orang (76\%). Pada dasarnya, usia dewasa terutama usia 50 ke atas memiliki risiko tinggi terhadap diabetes melitus. Prevalensi diabetes melitus akan meningkat seiring dengan bertambahnya usia, hal ini disebabkan karena pada usia tersebut mulai terjadi peningkatan intolenransi 
glukosa. Adanya proses penuaan menyebabkan berkurangnya kemampuan sel $\beta$ pankreas dalam memproduksi insulin. Selain itu, pada individu yang berusia lebih tua terdapat penurunan aktivitas mitokondria di sel-sel otot sebesar 35\% (Pardede,dkk., 2017). Diharapkan dengan bertambahnya usia pasien tingkat kepatuhan terhadap penggunaan ramuan jamu saintifik hiperglikemia juga semakin tinggi

Tabel 1. Karakteristik frekuensi pasien diabetes melitus di Rumah Riset Jamu Hortus Medicus B2P2TOOT Tawangmangu

\begin{tabular}{|c|c|c|c|c|}
\hline \multirow{2}{*}{ No } & Karakteristik & \multirow{2}{*}{ Klasifikasi } & \multirow{2}{*}{$\mathrm{N}$} & \multirow{2}{*}{$\begin{array}{c}\text { Persentase } \\
\qquad(\%)\end{array}$} \\
\hline & pasien & & & \\
\hline \multirow{2}{*}{1} & \multirow{2}{*}{ Usia } & $\leq 50$ & 2 & 24 \\
\hline & & $>50$ & 7 & 76 \\
\hline \multirow{2}{*}{2} & \multirow{2}{*}{ Jenis kelamin } & Laki-laki & 6 & 65 \\
\hline & & Perempuan & 3 & 35 \\
\hline \multirow{3}{*}{3} & \multirow{3}{*}{ Jenis Obat } & Kapsul & 7 & 73 \\
\hline & & Rebusan & 2 & 23 \\
\hline & & $\begin{array}{c}\text { Kapsul dan } \\
\text { Rebusan }\end{array}$ & 4 & 4 \\
\hline \multirow{5}{*}{4} & \multirow{5}{*}{ Pendidikan } & Tidak Sekolah & 2 & 2 \\
\hline & & SD & 2 & 25 \\
\hline & & SMP & 9 & 9 \\
\hline & & SMA & 2 & 28 \\
\hline & & Akademi/PT & 3 & 36 \\
\hline \multirow{6}{*}{5} & \multirow{6}{*}{ Pekerjaan } & Tidak Bekerja & 2 & 2 \\
\hline & & Wiraswasta & 3 & 35 \\
\hline & & $\begin{array}{c}\text { PNS/TNI/ } \\
\text { POLRI }\end{array}$ & 2 & 23 \\
\hline & & $\begin{array}{c}\text { Karyawan } \\
\text { Swasta }\end{array}$ & 4 & 4 \\
\hline & & $\begin{array}{c}\text { Ibu Rumah } \\
\text { Tangga }\end{array}$ & 8 & 8 \\
\hline & & Lain-lain & 2 & 28 \\
\hline \multirow{3}{*}{6} & \multirow{3}{*}{$\begin{array}{c}\text { Lama } \\
\text { Menderita }\end{array}$} & $<1$ tahun & 2 & 22 \\
\hline & & $1-5$ tahun & 4 & 51 \\
\hline & & $>5$ tahun. & 2 & 27 \\
\hline
\end{tabular}

3. Karakteristik pasien diabetes melitus berdasarkan jenis kelamin

Pada penelitian ini pengambilan data jenis kelamin pasien digunakan untuk mengetahui perbandingan pasien DM laki-laki dan perempuan di Rumah Riset Jamu Hortus Medicus B2P2TOOT Tawangmangu. Distribusi frekuensi pasien DM berdasarkan jenis kelamin dapat dilihat pada Tabel 1. Berdasarkan Tabel 1 menunjukkan hasil distribusi frekuensi pasien diabetes melitus berdasarkan jenis kelamin di Rumah Riset Jamu Hortus Medicus B2P2TOOT Tawangmangu dapat diketahui bahwa kategori jenis kelamin terbanyak yaitu pada laki-laki dengan 62 orang (65\%). Kategori jenis kelamin laki-laki yang terkena diabetes melitus lebih banyak dari pada perempuan karena dipengaruhi oleh distribusi lemak tubuh pada laki-laki, penumpukan lemak terkonsentrasi di sekitar perut sehingga memicu obesitas sentral yang lebih berisiko memicu gangguan metabolisme (Pardede,dkk., 2017).

\section{Karakteristik pasien diabetes melitus berdasarkan jenis obat}

Pada penelitian ini pengambilan data jenis obat pasien digunakan untuk mengetahui jenis obat yang digunakan pasien DM di Rumah Riset Jamu Hortus Medicus B2P2TOOT Tawangmangu. Distribusi frekuensi pasien DM berdasarkan jenis obat dapat dilihat pada (tabel $1)$.

Berdasarkan (tabel 1) menunjukkan hasil distribusi frekuensi pasien diabetes melitus berdasarkan jenis obat di Rumah Riset Jamu Hortus Medicus B2P2TOOT Tawangmangu dapat diketahui kategori jenis obat terbanyak yaitu pasien yang memilih obat kapsul sebanyak 70 orang $(73 \%)$. Jenis obat tersebut yang sering diresepkan dalam 1 bulan. Pasien lebih memilih obat kapsul karena lebih praktis, mudah dibawa saat berpergian, langsung diminum tanpa pengolahan terlebih dahulu, sedangkan yang rebusan harus melalui tahap pengolahan yaitu satu kemasan direbus dengan 5 gelas (@200 cc) air sampai mendidih sehingga air tinggal 3 gelas diminum pagi, siang, dan sore, satu kemasan untuk satu hari, hari berikutnya merebus kemasan yang baru. Pasien yang memiih jenis obat kapsul dan 
rebusan dalam 1 bulan bertujuan untuk masa penyesuaian penggunaan sediaan obat. Dalam hal ini pasien tidak mempermasalahkan dengan bentuk sediaan. Akan tetapi, dengan motivasi yang tinggi dalam pengobatan sehingga diharapkan kepatuhan pasien terhadap penggunaan ramuan jamu saintifik hiperglikemia juga tinggi

\section{Karakteristik pasien diabetes melitus berdasarkan pendidikan}

Pada penelitian ini pengambilan data pendidikan pasien digunakan untuk mengetahui pendidikan pasien DM yang melakukan pengobatan di Rumah Riset Jamu Hortus Medicus B2P2TOOT Tawangmangu. Distribusi frekuensi pasien DM berdasarkan pendidikan dapat dilihat pada tabel 1 .

Berdasarkan tabel 1 menunjukkan hasil distribusi frekuensi pasien diabetes melitus berdasarkan pendidikan di Rumah Riset Jamu Hortus Medicus B2P2TOOT Tawangmangu dapat diketahui bahwa pasien yang paling banyak mengidap penyakit DM yaitu pendidikan Akademi/Perguruan Tinggi sebanyak 34 orang $(36 \%)$. Menurut Heryati (2014) seseorang yang berpendidikan lebih tinggi akan mempunyai pengetahuan yang lebih luas dibandingkan dengan seseorang yang tingkat pendidikannya lebih rendah karena pendidikan merupakan dasar utama untuk keberhasilan dalam pengobatan. Hal ini diharapkan akan selaras dengan kepatuhan pasien terhadap penggunaan ramuan jamu saintifik hiperglikemia.

\section{Karakteristik pasien diabetes melitus berdasarkan pekerjaan \\ Pada penelitian ini pengambilan data} pekerjaan pasien digunakan untuk mengetahui pekerjaan pasien DM yang melakukan pengobatan di Rumah Riset Jamu Hortus Medicus B2P2TOOT Tawangmangu. Distribusi frekuensi pasien DM berdasarkan pendidikan dapat dilihat pada tabel 1 .

Berdasarkan tabel 1 menunjukkan hasil distribusi frekuensi pasien diabetes melitus berdasarkan pekerjaan di Rumah Riset Jamu Hortus Medicus B2P2TOOT Tawangmangu dapat diketahui bahwa pasien yang paling banyak mengidap penyakit DM yaituwiraswasta dengan 33 orang (35\%). Pekerjaan pasien berkaitan dengan jadwal kerja pasien yang bekerja terlalu padat membuat pengambilan obat atau kontrol terapi pengobatan terkadang sering lupa yang menyebabkan jadwal minum obat pasien yang tidak sesuai dengan aturan dokter (Adisa, dkk., 2009).

\section{Karakteristik pasien diabetes melitus berdasarkan lama menderita}

Pada penelitian ini pengambilan data lama menderita pasien digunakan untuk mengetahui sudah berapa lama pasien menderita penyakitDM yang melakukan pengobatan di Rumah Riset Jamu Hortus Medicus B2P2TOOT Tawangmangu. Distribusi frekuensi pasien DM berdasarkan pendidikan dapat dilihat pada tabel 1.

Berdasarkan hasil penelitian bahwa lamanya pasien menderita penyakit diabetes melitus lebih banyak selama 1-5 tahun dengan 49 orang $(51 \%)$. Durasi atau lamanya menderita penyakit diabetes melitus ini tidak dapat menjamin bahwa waktu tersebut menggambarkan waktu yang sebenarnya mengalami diabetes melitus, hanya saja pasien baru mengetahui diabetes melitus setelah terjadinya komplikasi dan akhirnya pasien datang ke rumah sakit (Lestari, 2013).

\section{Tingkat Kepatuhan Penderita Diabetes Melitus}

Kepatuhan pengobatan adalah kesesuaian pasien terhadap anjuran atas medikasi yang telah diresepkan yang terkait dengan waktu, dosis, dan frekuensi. Pasien harus mengikuti perintah dari dokter dan mematuhi aturan dokter agar pasien tidak membuat keputusan sendiri dalam penggunaan obat. Konsep kepatuhan menyatakan gagasan bahwa mengikuti anjuran tenaga medis merupakan tindakan yang tepat dan hal yang terbaik untuk pasien. Pasien yang patuh terhadap terapi pengobatan diharapkan dapat meningkatkan keberhasilan terapi dan mencegah komplikasi. Salah satu faktor yang berperan dalam kegagalan pengontrolan glukosa darah pasien diabetes melitus tipe adalah faktor ketidakpatuhan pasien terhadap pengobatan. Faktor yang memengaruhi ketidakpatuhan pengobatan dan penyakit antara lain faktor 
pasien, faktor demografi, sosio ekonomi, durasi atau lamanya penyakit, dan keparahan penyakit (Rasdianah, dkk., 2016).

Pada penelitian ini pengambilan data kepatuhan pasien digunakan untuk mengetahui tingkat kepatuhan pasien DM yang melakukan pengobatan di Rumah Riset Jamu Hortus Medicus B2P2TOOT Tawangmangu. Distribusi frekuensi pasien DM berdasarkan kepatuhan dapat dilihat pada Gambar 1.

Kepatuhan dinilai berdasarkan skor atau nilai yang didapat dari hasil kuesioner kepatuhan. Kuesioner ini terdiri dari 8 item pertanyaan untuk mengukur kepatuhan penggunaan obat dengan rentang nilai 0 sampai 8. Kategori respon terdiri dari ya dan tidak. Item nomor 1 sampai 4 dan 6 sampai 7 nilai 1 untuk jawaban tidak. Item 5 nilai 1 untuk jawaban ya dan 5 skala likert untuk 1 item pertanyaan nomor 8 dengan nilai 1 untuk jawaban tidak pernah, 0,75 untuk jawaban beberapa kali, 0,5 kadangkadang, 0,25 biasanya dan 0 selalu. Kategori kepatuhan diklasifikasikan menjadi 3 yaitu tinggi, sedang, rendah. Berdasarkan kuesioner tersebut apabila mendapat skor $=8$ maka dikategorikan tingkat kepatuhannya tinggi, jika skor $=$ 6-7 maka tingkat kepatuhannya sedang dan jika skor $<6$ maka dikategorikan tingkat kepatuhannya rendah.

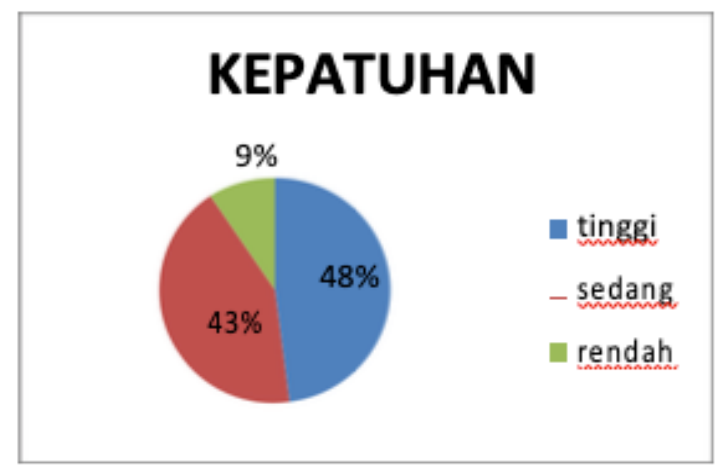

\footnotetext{
Gambar 1. Distribusi frekuensi pasien diabetes melitus berdasarkan tingkat kepatuhan di Rumah Riset Jamu Hortus Medicus B2P2TOOT Tawangmangu
}

Berdasarkan hasil penelitian, tingkat kepatuhan terbesar yang ada di Rumah Riset Jamu Hortus Medicus B2P2TOOT Tawangmangu adalah kategori tinggi dengan sejumlah (48\%). Hal ini karena pasien kebanyakan sudah paham mengenai informasi maupun edukasi terkait dengan penggunaan ramuan jamu saintifik yang ada di Rumah Riset Jamu Hortus Medicus B2P2TOOT Tawangmangu dan diminum sesuai anjuran dari dokter.

Kepatuhan pasien diabetes melitus dipengaruhi karakteristik dari penyakit dan pengobatannya kompleksitas dari pengobatan, lamanya penyakit yang memberikan efek negatif terhadap kepatuhan pasien. Makin lama pasien mengidap penyakit diabetes, makin kecil pasien tersebut patuh pada pengobatannya serta cara pemberian pelayanan yang harus intensif dan multidisiplin pada tim tenaga medis untuk mencapai keberhasilan terapi pasien, faktor intra-personal (umur, jenis kelamin, penghargaan terhadap diri sendiri, disiplin diri, stres, depresi dan penyalahgunaan alkohol), faktor inter-personal (kualitas hubungan antara pasien dan petugas pelayanan kesehatan dan dukungan keluarga) dan faktor lingkungan.

\section{Faktor-Faktor Korelasi Kepatuhan}

Faktor - faktor yang mempengaruhi ketidakpatuhan ada 4 kategori faktor pasien, faktor penyakit, faktor regimen terapi, dan faktor interaksi dengan praktisi kesehatan (Brown dan Bussell, 2011). Akan tetapi, pada penelitian ini yang akan dibahas adalah faktor usia, jenis kelamin, jenis obat, pendidikan, pekerjaan, lama menderita terhadap kategori tingkat kepatuhan pasien yang ditunjukkan pada Tabel 2. 
Tabel 2. Hasil analisis korelasi antara karakteristik pasien terhadap tingkat kepatuhan di Rumah Riset Jamu Hortus Medicus B2P2TOOT Tawangmangu

\begin{tabular}{|c|c|c|c|c|c|}
\hline No & Klasifikasi & $\mathrm{N}$ & $\begin{array}{c}\text { Persenta } \\
\text { se }(\%)\end{array}$ & $\begin{array}{c}\text { Korelasi } \\
\text { Arah }\end{array}$ & $\begin{array}{c}p \\
\text { value }\end{array}$ \\
\hline \multirow{2}{*}{1} & $\leq 50$ & 23 & 24 & \multirow[b]{2}{*}{0,261} & \multirow[b]{2}{*}{0,010} \\
\hline & $>50$ & 73 & 76 & & \\
\hline \multirow{2}{*}{2} & Laki-laki & 62 & 65 & \multirow[b]{2}{*}{0,089} & \multirow[b]{2}{*}{0,391} \\
\hline & Perempuan & 34 & 35 & & \\
\hline \multirow{3}{*}{3} & Kapsul & 70 & 73 & \multirow{3}{*}{0,0690} & \multirow{3}{*}{0,504} \\
\hline & Rebusan & 22 & 23 & & \\
\hline & $\begin{array}{c}\text { Kapsul dan } \\
\text { Rebusan }\end{array}$ & 4 & 4 & & \\
\hline \multirow{5}{*}{4} & Tidak Sekolah & 2 & 2 & \multirow{5}{*}{0,019} & \multirow{5}{*}{0,854} \\
\hline & SD & 24 & 25 & & \\
\hline & SMP & 9 & 9 & & \\
\hline & SMA & 2 & 28 & & \\
\hline & Akademi/PT & 27 & 28 & & \\
\hline \multirow{6}{*}{5} & Tidak Bekerja & 2 & 2 & \multirow{6}{*}{0,108} & \multirow{6}{*}{0,295} \\
\hline & Wiraswasta & 33 & 35 & & \\
\hline & $\begin{array}{c}\text { PNS/TNI/ } \\
\text { POLRI }\end{array}$ & 22 & 23 & & \\
\hline & $\begin{array}{c}\text { Karyawan } \\
\text { Swasta }\end{array}$ & 4 & 4 & & \\
\hline & $\begin{array}{c}\text { Ibu Rumah } \\
\text { Tangga }\end{array}$ & 8 & 8 & & \\
\hline & Lain-lain & 27 & 28 & & \\
\hline \multirow{3}{*}{6} & $<1$ tahun & 21 & 22 & \multirow{3}{*}{0,165} & \multirow{3}{*}{0,108} \\
\hline & $1-5$ tahun & 49 & 51 & & \\
\hline & $>5$ tahun. & 26 & 27 & & \\
\hline
\end{tabular}

\subsection{Faktor usia}

Pada hasil penelitian yang disajikan tabel 2 dapat dilihat bahwa korelasi antara kepatuhan dengan usia sebesar $0,010 \quad(p<0,05)$ yang menunjukkan bahwa korelasi antara usia dengan kepatuhan minum obat dikategorikan memiliki hubungan yang bermakna. Hal ini karena penuaan mempengaruhi banyak hormon yang mengatur metabolisme, reproduksi, dan fungsi organ lain (Triplitt dkk., 2005).

\subsection{Faktor jenis kelamin}

Pada hasil penelitian yang disajikan tabel 2 dapat dilihat bahwa korelasi antara kepatuhan dengan jenis kelamin sebesar 0,391 $(p>0,05)$ yang menunjukkan bahwa korelasi antara jenis kelamin dengan kepatuhan minum obat tidak ada hubungan bermakna. Hasil ini dikarenakan jenis kelamin merupakan faktor risiko diabetes melitus yang tidak dapat dimodifikasi (Kemenkes RI, 2014). Hasil penelitian Sweileh et al (2014) di Palestina juga menyebutkan bahwa tidak menunjukkan hubungan yang bermakna antara kepatuhan minum obat terhadap jenis kelamin dengan nilai $p=0,58$ $(p>0,05)$.

\subsection{Faktor jenis obat}

Pada hasil penelitian yang disajikan tabel 2 dapat dilihat bahwa korelasi antara kepatuhan dengan jenis obat sebesar 0,504 $(p>0,05)$ yang menunjukkan bahwa korelasi antara jenis obat dengan kepatuhan tidak ada hubungan yang bermakna. Hal ini dikarenakan pasien tidak mempermasalahkan dengan bentuk sediaan jenis obat.

\subsection{Faktor pendidikan}

Pada hasil penelitian yang disajikan tabel 2 dapat dilihat bahwa korelasi antara pendidikan dengan kepatuhan sebesar 0,854 $(p>0,05)$ yang menunjukkan bahwa korelasi antara pendidikan dengan kepatuhan tidak ada hubungan yang bermakna. Hasil penelitian ini sama dengan penelitian Tombokan (2015) yang menunjukkan nilai $p=0,611>0,05$ yang menunjukkan tidak terdapat hubungan yang bermakna antara pendidikan pasien dengan kepatuhan berobat. Faktor yang memengaruhi kepatuhan seseorang dalam berobat yaitu faktor petugas, faktor obat, dan factor penderita. Karakteristik petugas yang memengaruhi kepatuhan antara lain jenis petugas, tingkat pengetahuan, lamanya bekerja, frekuensi penyuluhan yang dilakukan (Tombokan, 2015). 


\subsection{Faktor pekerjaan}

Pada hasil penelitian yang disajikan tabel 2 dapat dilihat bahwa korelasi antara pekerjaan dengan kepatuhan sebesar 0,295 $(p>0,05)$ yang menunjukkan bahwa korelasi antara pekerjaan dengan kepatuhan tidak ada hubungan yang bermakna. Hasil penelitian ini berbeda dengan Adisa dkk. (2009), bahwa pekerjaan mempunyai pengaruh yang signifikan dengan nilai $\mathrm{p}=0,005$ terhadap tingkat kepatuhan dalam minum obat pada pasien DM tipe-2. Hal ini dikarenakan dengan adanya jadwal kerja yang terlalu padat terutama pada pasien yang bekerja, membuat pengambilan obat atau kontrol terapi pengobatan terlupakan, sehingga menyebabkan jadwal minum obat yang tidak sesuai dengan aturan dokter (Adisa, dkk., 2009).

\subsection{Faktor lama menderita}

Pada hasil penelitian yang disajikan tabel 2 dapat dilihat bahwa korelasi antara kepatuhan dengan lama menderita sebesar 0,108 $(p>0,05)$ yang menunjukkan bahwa korelasi antara lama menderita dengan kepatuhan tidak ada hubungan yang bermakna. Hal ini dikarenakan kemungkinan lamanya penyakit merupakan faktor yang tidak dapat dimodifikasi dan pasien yang terdiagnosa diabetes melitus baik lama atau baru mempunyai emosi yang sama seperti sering menyangkal, marah, dan cemas (Ulum, dkk., 2014). Hasil penelitian ini sama dengan hasil penelitian (Ulum, dkk., 2014), yang menyatakan bahwa tidak ada hubungan yang bermakna antara lamanya penyakit diabetes melitus terhadap kepatuhan minum obat dengan nilai $p=0,618$.

Masalah ketidakpatuhan penggunaan obat pada pasien diabetes melitus masih banyak dilakukan baik disengaja maupun tidak disengaja, sehingga perlu pengatasan seperti peran farmasi dalam memberikan edukasi yang bertujuan untuk mengukur seberapa pemahaman, pengetahuan, keterampilan pasien dalam menjalankan terapi dan memonitoring misalnya, membuat leafleat, booklet, tentang pentingnya pengobatan pada pasien diabetes melitus, melakukan konseling atau pelayanan informasi obat pada pasien diabetes melitus, dan melakukan kunjungan di rumah, khususnya bagi kelompok lansia dan pasien dengan pengobatan penyakit kronis lainnya (Kemenkes RI, 2015). Adapun peran pasien yaitu mematuhi regimen terapi yang sudah diberikan, ikut serta dalam memonitor efek samping obat, aktif dalam mencari informasi dan berbagi pengalaman dalam menjalankan terapi kepada farmasi setiap kontrol pengobatan (Keban dan Purnomo, 2013).

\section{Kesimpulan}

\section{Kesimpulan}

Tingkat kepatuhan penggunaan ramuan jamu saintifik hiperglikemia pada pasien diabetes melitus di Rumah Riset Jamu Hortus Medicus B2P2TOOT Tawangmangu yaitu tergolong kategori tinggi sebesar 48\%, kategori sedang sebesar $43 \%$ dan kategori rendah sebesar 9\%.

\section{Daftar Pustaka}

Adisa, R., Alutundu, M. B., danFakeye, T. O., 2009,Factors Contributing to Nonadherence to Oral Hypoglycemic Medications Among Ambulatory Type 2 Diabetes Patients in Southwestern Nigeria. Pharmacy Practice, 7(3), 163-169.

Ahmad AF., 2012, Analisis Penggunaan Jamu Untuk Pengobatan Pada Pasien Di Klinik Saintifikasi Jamu Hortus Medicus Tawangmangu, Tesis Program Pasca Sarjana Ilm Kesehatan Masyrarakat, Fakultas Kesehatan Masyarakat, Depok

Ainni, A. N.,dan Mutmainah, N., 2017, Studi Kepatuhan Penggunaan Obat Pada Pasien Diabetes Melitus Tipe-2 Di Instalasi Rawat Jalan Rsud Dr. Tjitrowardojo Purworejo Tahun 2017, Doctoral dissertation, Universitas Muhammadiyah Surakarta.

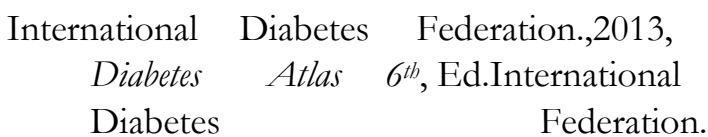


Keban, S. A., dan Purnomo, L. B., 2013,Evaluasi Hasil Edukasi Farmasis Pada Pasien Diabetes MelitusTipe 2 di Rumah Sakit Dr. Sardjito Yogyakarta, Jurnal Ilmu Kefarmasian Indonesia, 11(1), 4552.

Kementerian Kesehatan RI., 2015, Laporan Akuntabilitas Kinerja 2015, Direktorat Jendral Bina Kefarmasian dan Alat Kesehatan RI, Jakarta.

Kemenkes., 2017, Jати Saintifik, (3), Karanganyar, B2P2TOOT.

Lestari D,T., 2013, Faktor-Faktor Yang Mempengaruhi Inisiasi Insulin Pada Pasien Diabetes Melitus Tipe-2 Di Rumah sakit Daerah Kabupaten Kudus, Tesis, Magister Ilmu Keperawatan. Universitas Indonesia.

Morisky DE., 2008, Predictive Validity of a Medication Adherence Measure in an Outpatient Setting, The Journal Of Clinical HypertentionVol.10(5):348-354.

Nur Rasdianah., Suwaldi M., Tri MA., 2016, Gambaran Kepatuhan Pengobatan Pasien Diabetes Melitus Tipe 2 di Puskesmas Daerah Istimewa Yogyakarta, Jurnal Farmasi Klinik Indonesia, Pascasarjana Fakultas Farmasi, Universitas Gadjah Mada, Yogyakarta, Indonesia.

Oktadiansyah D., 2014, Kepatuhan Minum Obat Diabetes Pada Pasien Diabetes Melitus Tipe 2, Tesis, Program Studi Sarjana Fakultas Ilmu Keperawatan, Universitas Indonesia, Jakarta.

Pahandayani, P., 2014., FaktorFaktor yang berhubungan Dengan Pemilihan Pengobatan Alternatif Jamu Pada Pasien Diabetes Melitus Di Rumah Riset Jamu Hortus Medicus Tawangmangu, Doctoral dissertation, Universitas Muhammadiyah Surakarta.

Ulum, Z., Kusnanto, danWidyawati, I. Y., 2014, Kepatuhan Medikasi Penderita Diabetes Melitus Tipe-2 Berdasarkan Teori Haelth Belief Model (HBM) di Wilayah Kerja
Puskesmas Mulyorejo Surabaya, Skripsi,

Fakultas Kedokteran, Universitas Airlangga 